\title{
KEPUTUSAN PEMERINTAH BERBASIS LAPORAN KEUANGAN DALAM PERSPEKTIF POLITIK ANGGARAN
}

\author{
I Putu Sudano', Nyoman Sri Subawa ${ }^{2}$ \\ 1,2Program Studi Magister Administrasi Publik Program Pasca Sarjana, \\ Universitas Pendidikan Nasional Denpasar \\ Jl. Waturenggong No.164 Denpasar, Bali \\ Email: radeaananda09@gmail.com ${ }^{(1)}$ shribawa@undiknas.ac.id (2)
}

Article Histori:

Submited: 04/01/2020

Editing: $29 / 04 / 2020$

Publish: 30/04/2020

\begin{abstract}
This study aims to determine the extent uses of data and information that contain in the regional financial report (LPKD) is used in decision making by the Provincial Government of Bali in preparing the APBD. The research method used is a qualitative descriptive analysis by comparing the concept of decision making for budgeting according to Undang-Undang Nomor 23 Tahun 2014 concerning Regional Government with its application in the Provincial Government of Bali and the concept of decision making theory. Based on the results of the study it was found that the decision making in the preparation of the Bali Province APBD there were several weaknesses, including the lack of a link between the decision making in the preparation of the APBD of the local government financial reports. Also, the preparation of the Bali Provincial Government's APBD which is still based on Permendagri nomor 13 tahun 2016 concerning the evaluation of regional regulation designs, has not accommodated the performance and utilization of data, as well as information presented in the financial statements. Thus, the use of information data in the regional government financial reports is not optimal as a decision for the preparation and design of the APBD.
\end{abstract}

Keyword: Government decisions, financial statements, budget politics.

\section{PENDAHULUAN}

Meningkatnya tuntutan masyarakat terhadap upaya mewujudkan tatanan pemerintahan yang baik (good governance government), mewajibkan pemerintah baik pusat dan daerah menerapkan akuntabilitas publik. Akuntabilitas dan transparansi pengelolaan keuangan pemerintah baik di tingkat pusat maupun di daerah adalah arti penting dalam mewujudkan reformasi birokrasi di tatanan pemerintahan. Good governance hanya dapat dicapai melalui tiga pilar utama yaitu adanya transparasi dari pemerintah, partisipasi dari masyarakat, dan adanya pertanggungjawaban

(akuntabilitas) 
penyelenggara pemerintahan atas pelaksanaan kegiatan. Salah satu bentuk pengaplikasian tiga pilar utama dari good governance adalah melalui penyusunan Anggaran.

APBD adalah instrument kebijakan fiskal Pemerintah Daerah. Jika terdapat selisih antara anggaran dengan realisasi dalam APBD maka, hal tersebut mengindikasikan tingkat akurasi yang rendah. hal tersebut dapat berdampak buruk bagi kualitas kebijakan atau keputusan pemerintah. Terutama pengambilan keputusan terkait dengan perencanaan dan penganggaran dalam menyusun APBD.

Pelaporan keuangan bertujuan menyediakan informasi penting dan fundamental dalam pengambilan keputusan untuk mewujudkan akuntabilitas dan transparansi pengelolaan keuangan. Kualitas laporan keuangan dan kecukupan data dan informasi serta ketepatan waktu dalam penyajian menjadi sangat penting, sehingga data dan informasi yang ada dalam laporan keuangan dapat digunakan untuk pengambilan keputusan dalam proses perencanaan dan penyusunan APBD.

Artikel ini bertujuan untuk mendeskripsikan sejauh mana pemanfaatan data dan informasi yang tersedia di LKPD terkait pengambilan keputusan oleh Pemerintah Provinsi Bali dalam menyusun Anggaran Pendapatan dan Belanja Daerah.

\section{KAJIAN LITERATUR}

Landasan teoritis

untuk mendeskripsikan pengambilan keputusan adalah dari Eisenfuhr (2011) yang mendefinisikan pengambilan keputusan sebagai serangkaian proses memilih alternative untuk mencapai tujuan yang diinginkan. Pengambilan keputusan ialah suatu pendekatan yang bersifat sistematis dalam mengakji permasalahan, mengumpulkan data dan menelaah alternative atau solusi yang ada dan menentukan pilihan solusi atas permasalahan tersebut. Dapat disimpulkan bahwa pengambilan keputusan yaitu memilih salah satu alternatif dari serangkaian alternatif yang tersedia (Afmansyah, 2019)

Peraturan Pemerintah Nomor 71 tahun 2010 tentang Standar Akuntansi Pemerintahan, Laporan keuangan merupakan laporan yang terstruktur mengenai posisi keuangan dan transaksitransaksi yang dilakukan oleh suatu entitas pelaporan. Secara umum laporan keuangan (LK) menyajikan posisi keuangan dan transaksi-transaksi suatu entitas. Secara umum LK bertujuan memberikan informasi yang dibutuhkan oleh pengguna terkait dengan transaksi yang dilakukan meliputi aset, kewajiban, ekuitas dana perusahaan.

Djanegara (2017) mendefinisikan laporan keuangan pemerintah merupakan wujud komitmen pemerintah dalam pengelolaan keuangan secara transparan dan akuntabel. Terdapat 7 komponen pokok LKPD yakni laporan realisasi anggaran, laporan perubahan saldo anggaran, neraca, laporan operasional, laporan arus kas, laporan perubahan ekuitas, catatan atas laporan keuangan.

Indikator LKPD yang berkualitas adalah (1) andal, (2) relevan, (3) dapat dipahami, dan (4) dapat dibandingkan. Laporan keuangan yang berkualitas menunjukkan bahwa Kepala Daerah bertanggung jawab sesuai dengan wewenang yang dilimpahkan kepadanya dalam pelaksanaan tanggung jawab mengelola organisasi.

Proses penentuan besaran dan alokasi anggaran senantiasa sarat dengan kepentingan politik yang melibatkan berbagai aktor di dalamnya. LKPD 
diharapkan mampu menghasilkan informasi yang bermanfaat bagi para pengguna dalam menilai akuntabilitas dan membuat keputusan baik untuk keputusan ekonomi sosial dan politik (Setyowati et al., 2016).

Penetapan suatu anggaran dipandang sebagai suatu kontrak kinerja antara legislatif dan eksekutif (Abdullah \& Asmara, 2006; Freeman \& Shoulders, 2003:94). Mardiasmo (2016) mendefinisikan penganggaran dalam organisasi sektor publik adalah tahapan yang cukup rumit dan mengandung nuansa politik yang tinggi.

\section{METODE PENELITIAN}

Penelitian ini dilakukan pada Badan Pengelola Keuangan dan Aset Daerah (BPKAD) Provinsi Bali. BPKAD Provinsi Bali mempunyai tugas melaksanakan fungsi penunjang urusan pemerintahan yang menjadi kewenangan daerah provinsi di bidang keuangan sub pengelolaan keuangan dan aset.

Penelitian bersifat deskriptif kualitatif dengan sumber data yang digunakan dalam penelitian ini dikumpulkan melalui informan. Pemilihan informan didasarkan pada kriteria khusus melalui teknik purposive sampling. Informan terdiri dari Kepala Badan Pengelola Keuangan dan Aset Daerah Provinsi Bali, Kepala Bidang Perencanaan Anggaran Daerah pada Badan Pengelola Keuangan dan Aset Daerah Provinsi Bali dan dari Inspektorat selaku aparatur pengawas internal pemerintah (APIP). Informan eksternal yang digunakan peneliti adalah dari Badan Pemeriksa Keuangan Kantor Perwakilan Denpasar dan dari Kantor Akuntan Publik/Konsultan/staf ahli DPRD Provinsi Bali.
Data dikumpulkan menggunakan wawancara terstruktur. Peneliti mempersiapkan panduan wawancara yang akan digunakan untuk menggali data pada informan. Data yang diperoleh diuji kembali untuk melihat keabsahan data dengan metode triangulasi data. Proses tersebut dilakukan hingga didapatkan data jenuh.

\section{HASIL DAN PEMBAHASAN}

Pelaku-pelaku kunci yang terkait dalam penyusunan anggaran Pemerintah Provinsi Bali adalah Pihak eksekutif mulai dari Kepala Daerah, Sekretaris daerah, Tim Anggaran Pemerintah Daerah (TAPD), Satuan Kerja Perangkat Daerah (SKPD), Badan Perencanaan Pembangunan Daerah (BAPPEDA), Badan Pengelola Keuangan dan Aset Daerah (BPKAD.

Tahapan pengambilan keputusan yang terjadi Menurut Kepala Bidang Perencanaan Anggaran Daerah (Kabid PAD) pada BPKAD Provinsi Bali, bahwa pembangunan daerah termasuk perencanaan keuangan dimulai dari Rencana Pembangunan Jangka Panjang Daerah (RPJPD) yaitu berupa dokumen perencanaan untuk periode 20 tahun yang memuat visi, misi dan arah pembangunan. Dari RPJPD kemudian diturunkan menjadi RPJMD memuat dokumen perencanaan pemerintah daerah untuk periode 5 tahun. Setiap ada pemilihan kepala daerah maka akan ada visi dan misi yang baru yang tetap mengacu kepada RPJPD. Dalam RPJMD turun menjadi visi, misi, sasaran, program, dan kegiatan yang dieksekusi setiap tahun menjadi RKPD yaitu dokumen perencanaan daerah untuk periode 1 tahun. RKPD ini menjadi sumber data untuk menyusun RAPBD.

Berdasarkan Undang-Undang Nomor 25 Tahun 2004 tentang Sistem Perencanaan Pembangunan Nasional pada pos penjelasan dinyatakan bahwa perencanaan 
pembangunan terdiri dari empat (4) tahapan yakni 1) Penyusunan rencana; 2)penetapan rencana; 3)pengendalian pelaksanaan rencana; dan 4) evaluasi pelaksanaan rencana.

\section{Proses Intelligence}

Tabel 1.

Perbandingan Tahapan Pengambilan Keputusan dalam Perumusan RKPD

\begin{tabular}{|c|c|c|c|}
\hline $\begin{array}{l}\text { Aktor dalam pengambilan } \\
\text { keputusan }\end{array}$ & $\begin{array}{l}\text { UU Nomor } 23 \\
\text { Tahun } 2014\end{array}$ & $\begin{array}{c}\text { Penerapan pada } \\
\text { Pemerintah Provinsi } \\
\text { Bali }\end{array}$ & Teori Tahapan Intelligence \\
\hline $\begin{array}{l}\text { Pemerintah Daerah dan } \\
\text { DPRD }\end{array}$ & $\begin{array}{lr}\text { Rencana } & \text { Strategis } \\
\text { Daerah, } & \text { Hasil } \\
\text { Penjaringan } & \\
\text { Aspirasi } & \\
\text { masyarakat, } \\
\text { Laporan Kinerja } \\
\text { Historis, Pokok- } \\
\text { pokok fikiran } \\
\begin{array}{l}\text { DPRD, Kebijakan } \\
\text { Keuangan Daerah }\end{array}\end{array}$ & $\begin{array}{lr}\text { Menetapkan } & \text { target } \\
\text { pendapatan melalui } \\
\text { forum pendapatan } \\
\text { daerah, } \\
\text { Melaksanakan } \\
\text { musrenbang } \\
\text { eksekutif } \text { (Renstra) } \\
\text { Daerah. Penjaringan } \\
\text { aspirasi r oleh } \\
\text { legislatif } & \text { (pokir). } \\
\text { Laporan } & \text { Kinerja } \\
\text { hirtoris, kebijakan } \\
\text { keuangan. }\end{array}$ & $\begin{array}{l}\text { Adalah tahapan } \\
\text { penelusuran dan } \\
\text { pendeteksian permasalahan } \\
\text { yang ada. seluruh data } \\
\text { diproses dan diuji untuk } \\
\text { mengidentifikasi } \\
\text { permasalahan yang dikaji. }\end{array}$ \\
\hline
\end{tabular}

Sumber: Hasil Penelitian, 2019

\section{Proses Design}

Tabel 2.

Perbandingan Tahapan Pengambilan Keputusan dalam Perumusan KUA

\begin{tabular}{|c|c|c|c|}
\hline $\begin{array}{c}\text { Aktor dalam } \\
\text { pengambilan } \\
\text { keputusan }\end{array}$ & $\begin{array}{c}\text { UU Nomor } 23 \text { Tahun } \\
2014\end{array}$ & $\begin{array}{c}\text { Penerapan pada } \\
\text { Pemerintah Provinsi } \\
\text { Bali } \\
\end{array}$ & Teori Tahapan Design \\
\hline Pemerintah Daerah & $\begin{array}{l}\text { Perumusan Kebijakan } \\
\text { Umum APBD dan } \\
\text { menghasilkan berita } \\
\text { acara kesepakatan }\end{array}$ & $\begin{array}{l}\text { Perumusan Kebijakan } \\
\text { Umum Anggaran } \\
\text { APBD dan } \\
\text { menghasilkan berita } \\
\text { acara kesepakatan }\end{array}$ & $\begin{array}{l}\text { Adalah tahapan penemuan } \\
\text { dan pengembangan alternative } \\
\text { solusi. Tahapan ini meliputi } \\
\text { pengidentifikasian masalah, } \\
\text { memilih dan menganalisasi } \\
\text { solusi yang dipilih }\end{array}$ \\
\hline
\end{tabular}

Sumber: Sumber: Hasil penelitian, 2019

\section{Proses Choice}

\section{Tabel 3.}

Perbandingan Tahapan Pengambilan Keputusan dalam Perumusan petunjuk Teknis APBD

\begin{tabular}{cccc}
\hline $\begin{array}{c}\text { Aktor dalam } \\
\text { pengambilan } \\
\text { keputusan }\end{array}$ & $\begin{array}{c}\text { UU Nomor 23 Tahun } \\
\mathbf{2 0 1 4}\end{array}$ & $\begin{array}{c}\text { Penerapan pada } \\
\text { Pemerintah Provinsi } \\
\text { Bali }\end{array}$ & Teori Tahapan Design \\
\hline TAPD & $\begin{array}{c}\text { Membuat Surat Edaran } \\
\text { Kepala Daerah tentang } \\
\text { Pedoman Penyusunan } \\
\text { Anggaran Unit Kerja } \\
\text { berdasarkan Perda }\end{array}$ & $\begin{array}{c}\text { Membuat Surat Edaran } \\
\text { Kepala Daerah tentang } \\
\text { Pedoman Penyusunan } \\
\text { Anggaran Unit Kerja } \\
\text { berdasarkan Perda }\end{array}$ & $\begin{array}{c}\text { Pada tahap ini } \\
\text { dilakukan poses } \\
\text { pemilihan di antara } \\
\text { berbagai alternatif } \\
\text { tindakan yang mungkin }\end{array}$ \\
\hline
\end{tabular}




\begin{tabular}{|c|c|c|c|}
\hline $\begin{array}{l}\text { Aktor dalam } \\
\text { pengambilan } \\
\text { keputusan }\end{array}$ & $\begin{array}{c}\text { UU Nomor } 23 \text { Tahun } \\
2014\end{array}$ & $\begin{array}{c}\text { Penerapan pada } \\
\text { Pemerintah Provinsi } \\
\text { Bali }\end{array}$ & Teori Tahapan Design \\
\hline & $\begin{array}{c}\text { Pengelolaan Keuangan, } \\
\text { KUA APBD, Strategi } \\
\text { dan Prioritas APBD, } \\
\text { Keputusan Kepala } \\
\text { Daerah tentang SPM, } \\
\text { tingkat Pencapaian } \\
\text { Kinerja dan Standar } \\
\text { Biaya }\end{array}$ & $\begin{array}{c}\text { Pengelolaan Keuangan, } \\
\text { KUA, Strategi dan } \\
\text { Prioritas APBD, } \\
\text { Keputusan Kepala } \\
\text { Daerah tentang SPM, } \\
\text { tingkat Pencapaian } \\
\text { Kinerja dan Standar } \\
\text { Biaya }\end{array}$ & $\begin{array}{l}\text { dijalankan. Tahap ini } \\
\text { meliputi pencarian, } \\
\text { evaluasi, dan } \\
\text { rekomendasi solusi } \\
\text { yang sesuai untuk } \\
\text { model yang telah } \\
\text { dibuat. Solusi dari } \\
\text { model merupakan nilai } \\
\text { spesifik untuk variabel } \\
\text { hasil pada alternatif } \\
\text { yang dipilih. }\end{array}$ \\
\hline \multirow[t]{3}{*}{ SKPD } & $\begin{array}{l}\text { Membuat Pernyataan } \\
\text { Anggaran berdasarkan } \\
\text { Perda ttg Struktur } \\
\text { Organisasi dan Tata } \\
\text { Kerja }\end{array}$ & $\begin{array}{l}\text { Membuat Pernyataan } \\
\text { Anggaran berdasarkan } \\
\text { Perda ttg Struktur } \\
\text { Organisasi dan Tata } \\
\text { Kerja }\end{array}$ & \\
\hline & $\begin{array}{l}\text { Membuat Pernyataan } \\
\text { Anggaran berdasarkan } \\
\text { Tujuan dan Sasaran } \\
\text { Unit Kerja }\end{array}$ & $\begin{array}{l}\text { Membuat Rencana Kerja } \\
\text { SKPD berdasarkan } \\
\text { Tujuan dan Sasaran } \\
\text { Unit Kerja }\end{array}$ & \\
\hline & $\begin{array}{l}\text { Membuat Pernyataan } \\
\text { Anggaran berdasarkan } \\
\text { program unit kerja }\end{array}$ & $\begin{array}{l}\text { Membuat RKA SKPD, } \\
\text { RKA PPKD berdasarkan } \\
\text { program unit kerja }\end{array}$ & \\
\hline
\end{tabular}

Sumber: Sumber: Hasil penelitian, 2019

\section{Proses Implementation}

Tabel 4.

Perbandingan Tahapan Pengambilan Keputusan dalam Perumusan Rancangan APBD

$\begin{array}{cccc}\begin{array}{c}\text { Aktor dalam } \\ \text { pengambilan }\end{array} & \text { UU Nomor 23 Tahun } & \begin{array}{c}\text { Penerapan pada } \\ \text { Pemerintah }\end{array} & \begin{array}{c}\text { Teori Tahapan } \\ \text { Implementation }\end{array}\end{array}$

keputusan

Provinsi Bali

\begin{tabular}{|c|c|c|c|}
\hline $\begin{array}{l}\text { Pemerintah Daerah dan } \\
\text { TAPD }\end{array}$ & $\begin{array}{l}\text { Membuat Rancangan } \\
\text { Perda APBD } \\
\text { berdasarkan Arah dan } \\
\text { KUA, Strategi dan } \\
\text { Prioritas APBD, } \\
\text { Anggaran Daerah }\end{array}$ & $\begin{array}{l}\text { Membuat } \\
\text { Rancangan Perda } \\
\text { APBD } \\
\text { berdasarkan Arah } \\
\text { dan KUA, Strategi } \\
\text { dan Prioritas } \\
\text { APBD, Anggaran } \\
\text { Daerah. }\end{array}$ & $\begin{array}{l}\text { Merupakan tahap } \\
\text { pelaksanaan dari } \\
\text { keputusan yang telah } \\
\text { diambil. Pada tahap ini } \\
\text { perlu disusun } \\
\text { serangkaian tindakan } \\
\text { yang terencana, } \\
\text { sehingga hasil }\end{array}$ \\
\hline $\begin{array}{l}\text { Badan Anggaran dan } \\
\text { TAPD }\end{array}$ & $\begin{array}{l}\text { Membuat Perda APBD } \\
\text { berdasarkan } \\
\text { Rancangan Perda } \\
\text { APBD }\end{array}$ & $\begin{array}{l}\text { Membuat Perda } \\
\text { APBD } \\
\text { berdasarkan } \\
\text { Rancangan Perda } \\
\text { APBD }\end{array}$ & $\begin{array}{l}\text { keputusan dapat } \\
\text { dipantau dan } \\
\text { disesuaikan apabila } \\
\text { diperlukan perbaikan. }\end{array}$ \\
\hline
\end{tabular}

Sumber: Hasil Penelitian, 2019

Pada tabel 1 dijelaskan terkait perbandingan tahapan pengambilan keputusan dalam perumusan RKPD. Pada tabel dapat dilihat tahapan pengambilan keputusan (Penyusunan RAPBD) menurut UU 23 Tahun 2014 pada dasarnya telah 
diterapkan oleh Pemerintah Provinsi Bali dan sesuai dengan konsep teori pengambilan keputusan. Namun, masih terdapat beberapa kelemahan antara lain dalam menentukan target pendapatan pemerintah daerah hanya melihat potensi daerah kedepan dan belum berupaya menggunakan berbagai metode melalui pendekatan realisasi sehingga target pendapatan belum mendekati riil. Disisi perencanaan belanja daerah, Pemerintah Provinsi Bali belum melakukan evaluasi terhadap laporan kinerja dan sistem perencanaan yang belum terintegrasi dengan sistem akuntabilitas kinerja intansi pemerintah, pemanfaatan laporan kinerja dalam sistem penganggaran belum maksimal.

Pada tabel 2 dijelaskan terkait perbandingan tahapan pengambilan keputusan dalam perumusan KUA. Tahapan Penyusunan Anggaran menurut UU 23 Tahun 2014 telah diterapkan oleh Pemerintah Provinsi Bali dan sesuai dengan konsep teori pengambilan keputusan. Namun dalam pembahasan antara Pemerintah Daerah dengan DPRD sering terjadi perdebatan karena adanya kepentingan kelompok dan golongan. Pembahasan KUA PPAS yang seharusnya mengacu pada RKPD yang sudah disepakati seringkali diingkari dengan berbagai alasan dan kepentingan kelompok masing-masing. Menurut informan yang penulis wawancarai yaitu staf ahli dewan (konsultan), lemahnya posisi tawar eksekutif terhadap legislatif karena apa yang disampaikan eksekutif terhadap legislatif tidak berbasis data dan informasi yang memadai sehingga perdebatan antara eksekutif dengan legislatif dalam pembahawan KUA PPAS tidak dapat dihindari.

Pada tabel 3 dijelaskan terkait perbandingan tahapan pengambilan keputusan dalam perumusan petunjuk teknis APBD. Pada tabel dapat dilihat tahapan pengambilan keputusan menurut UU 23 Tahun 2014 telah diterapkan oleh Pemerintah Provinsi Bali dan sesuai dengan konsep teori pengambilan keputusan. Namun masih ditemukan kelemahan terutama belum memperthatikan poin-poin penting dalam laporan keuangan pemerintah daerah. Dalam penyusunan RKA SKPD terutama pengklasifikasian kode rekening baik disisi pendapatan dan belanja belum mengakomodir beberapa temuan hasil pemeriksaan selama audit terhadap laporan keuangan pemerintah daerah tahun sebelumnya. Sehingga temuan-temuan berulang atas kesalahan penganggaran baik disisi pendapatan maupun belanja sering terjadi.

Pada tabel 4 dijelaskan perbandingan tahapan pengambilan keputusan dalam perumusan rancangan APBD. Pada tabel dapat dilihat tahapan penyusunan APBD menurut UU 23 tahun 2014 telah diterapkan oleh Pemerintah Provinsi Bali dan sesuai dengan konsep teori pengambilan keputusan. Namun masih ditemukan kelemahan seperti pada tahap verifikasi RKA-SKPD. Kesalahan yang ada pada RKASKPD sering kali lolos dari verifikasi. Disamping itu peran Aparat Pengawas Internal Pemerintah (APIP) yang dilakukan oleh Inspektorat untuk mereview RAPBD juga belum maksimal.

Temuan lain didapatkan permasalahan dan kendala yang dihadapi dalam pengambilan keputusan berbasis laporan keuangan dalam perspektif politik anggaran dari hasil wawancara dengan informan. Hasil penelitian akan dipaparkan pada penjelasan dibawah ini

1. Keterbatasan Sumber Daya Manusia.

Pada tabel 5 akan dipaparkan data hasil triangulasi data sumber permasalahan keterbatasan SDM. Data triangulasi data didapatkan dari hasil wawancara dengan informan penelitian dapat ditarik 
kesimpulan bahwa faktor keterbatasan SDM yang dimiliki menjadi permasalahan mendasar dalam penyusunan RAPBD, hal ini disebabkan oleh kurangnya pendidikan (pelatihan) yang berkelanjutan sesuai perkembangan regulasi terkait penyusunan RAPBD yang sangat dinamis serta faktor penempatan SDM yang kurang memaksimalkan analisis jabatan.

2. Manajemen waktu yang tidak efektif dan sesuai time table kegiatan.

Berdasarkan hasil observasi didapatkan bahwa penyusunan Peraturan Daerah tentang Pertanggungjawaban Pelaksanaan APBD beririsan dengan penyusunan APBD yang sangat signifikan. Hal ini menyebabkan dalam penyusunan RAPBD tidak bisa menggunakan data dan informasi terkini dari LKPD. Hasil ini sejalan dengan hasil wawancara yang menunjukkan bahwa semua informan sepakat bahwa manajemen waktu penetapan Peraturan Daerah tentang pertanggunjawaban pelaksanaan APBD dengan penyusunan RAPBD menjadi kendala bagi Pemerintah Daerah untuk memperoleh data dan informasi terkini yang tersaji dalam LKPD untuk digunakan dalam penyusunan RAPBD.

3. Laporan Keuangan Pemerintah Daerah belum digunakan sebagai acuan dalam alokasi anggaran.
Berdasar pada paparan data pada hasil wawancara di dapatkan bahwa Pemerintah Provinsi Bali belum menjadikan data dan informasi yang ada pada LKPD sebagai acuan dalam penentuan target pendapatan dan pengalokasian anggaran belanja daerah 4. Lemahnya fungsi pengawasan yang dilakukan oleh Aparat Pengawas Internal Pemerintah (APIP).

Hal ini dikarenakan keterbatasan personil yang dimiliki dan waktu yang sangat terbatas untuk melaksanakan fungsi pengawasan. Disamping itu belum adanya mekanisme khusus untuk monitoring pelaksanaan atas catatan hasil review (CHR) dan belum terdapat sanksi untuk pemerintah yang tidak melaksanakan review. CHR hanya menjadi sebuah catatan yang disampaikan kepada Direktorat jenderal bina pembangunan daerah kementerian dalam negeri dan tidak memiliki kepastian atas tindak lanjutnya. Hal yang sama juga disampaikan oleh staf ahli DPRD bahwa peran APIP masih sangat minim dalam penyusunan RAPBD.

5. Kurang Efektifnya evaluasi RAPBD yang dilakukan oleh Kemendagri.

Evaluasi yang kurang efektif dikarenakan belum terdapat mekanisme khusus untuk monitoring pelaksanaan hasil evaluasi dan belum terdapat mekanisme sanksi yang jelas dan ajeg bagi para pelanggar atauran.

Tabel 5.

Hasil triangulasi sumber Permasalahan Keterbatasan SDM

\begin{tabular}{lllll}
\hline Permasalahan & $\begin{array}{c}\text { Informan 1 } \\
\text { (Kepala BPKAD) }\end{array}$ & $\begin{array}{c}\text { Informan 2 } \\
\text { (Kabid } \\
\text { PAD) }\end{array}$ & $\begin{array}{l}\text { Informan 3 } \\
\text { (Konsultan) }\end{array}$ & $\begin{array}{c}\text { Triangulasi hasil } \\
\text { wawancara }\end{array}$ \\
\hline Keterbatasan SDM & Faktor SDM & SDM & Dari yang & SDM menjadi faktor \\
& memang menjadi & memang & kami temui & kunci dalam \\
& kendala dalam & menjadi & dilapangan & penyusunan \\
& pengelolaan & kendala & sebagi & RAPBD yang \\
& keuangan daerah, & dalam & konsultan & disebabkan karena \\
& pesatnya & pengelolaan & yang & kurangnya \\
\hline
\end{tabular}




$\begin{array}{llll}\text { pernyempurnaan } & \text { keuangan } & \text { mendampingi } & \text { pelatihan, mutasi } \\ \text { regulasi tidak } & \text { daerah } & \text { DPRD, sitem } & \text { yang tidak } \\ \text { diimbangi dengan } & \text { secara } & \text { perencanaan } & \text { mempertimbangkan } \\ \text { pendidikan yang } & \text { umum, } & \text { kita memang } & \text { latar belakang } \\ \text { berkelanjutan } & \text { analisis } & \text { belum } & \text { pendidikan dan } \\ \text { terhadap SDM } & \text { jabatan dan } & \text { maksimal, } & \text { perubahan regulasi } \\ \text { yang dimiliki } & \text { penempatan } & \text { salah satu } & \text { yang sangat } \\ & \text { SDM tidak } & \text { faktornya } & \text { dinamis. } \\ & \text { berjalan } & \text { adalah SDM } & \\ & \text { dengan baik. } & \text { yang masih } & \\ & & \text { kurang } & \\ & & \text { terlatih. } & \end{array}$

Sumber: Sumber: Hasil penelitian, 2019

\section{PENUTUP}

Kesimpulan dari penelitian ini adalah Pemerintah Provinsi Bali belum menjadikan laporan keuangan sebagai instrumen penyusunan APBD, sehingga laporan yang tersusun bersifat terperinci dan efektif, sehingga anggaran pendapatan dan belanja daerah belum tersusun secara efektif. Hal tersebut disebabkan oleh berbagai kendala yakni keterbatasan SDM, manajemen waktu Penyusunan LKPD dengan penyusunan RAPBD, lemahnya fungsi pengawasan oleh APIP dan belum efektifnya evaluasi oleh Kemendagri. Diharapkan adanya penelitian lebih lanjut kedepan agar dapat melengkapi kekurangan dan keterbatasan data yang ada pada penelitian ini.

\section{DAFTAR PUSTAKA}

Abdullah. S dan Asmara, J.A. 2006. Perilaku Oportunistik Legislatif Dalam Penganggaran Daerah - Bukti Empiris atas Aplikasi Agency Theory di Sektor Publik. Simposium Nasional Akuntansi (SNA). Palembang. 2006.

Afmansyah, T. H. (2019). Kendala-Kendala dalam Pengambilan Keputusan. 1-3. Universitas Negeri Padang.
Arikunto, Suharsimi. (2010). Prosedur Penelitian Suatu Pendekatan Praktik. Yogyakarta: Rineka Cipta.

Djanegara, Moermahadi S. 2017. Laporan Keuangan Pemerintah Daerah. Teori, Praktik, dan Permasalahan. Yogyakarta: Kesatuan Press.

Eisenfuhr, F. (2011). Decision Making. New York: Springer.

Mahmudi. 2016. Analisis laporan keuangan pemerintah daerah. Yogyakarta: Penerbit Sekolah tinggi ilmu manajemen YKPN.

Setyowati, Lilis. dkk. 2016. Faktor-Faktor Yang Mempengaruhi Kualitas Laporan Keuangan Pemerintah Daerah Kota Semarang. Volume 20, No.2, Hal. 179-191

------- Undang-Undang Nomor 9 Tahun 2015 tentang Perubahan Kedua Atas Undang-Undang Nomor 23 Tahun 2014 tentang Pemerintahan Daerah; Lembaran Negara Republik Indonesia Tahun 2015 Nomor 58;

Undang-Undang Nomor 23 Tahun 2014 Tentang Pemerintah Daerah; Lembaran Negara Republik Indonesia Tahun 2014 Nomor 244;

Tahun 2004 Tentang Keuangan
Negara; Lembaran Negara Republik
Indonesia Tahun 2003 Nomor 47;


- Peraturan Pemerintah Nomor 71 Tahun 2010 Tentang Standar Akuntansi Pemerintahan; Lembaran Negara Republik Indonesia Tahun 2010 Nomor 123, Tambahan
Lembaran Negara Republik Indonesia Nomor 5165 - Peraturan Pemerintah Nomor 12 Tahun 2019 Tentang Pengelolaan Keuangan Daerah. 